This item was submitted to Loughborough's Research Repository by the author.

Items in Figshare are protected by copyright, with all rights reserved, unless otherwise indicated.

\title{
Evaluating social value in the UK construction industry
}

PLEASE CITE THE PUBLISHED VERSION

https://doi.org/10.1680/jmapl.17.00051

PUBLISHER

() ICE Publishing

VERSION

AM (Accepted Manuscript)

PUBLISHER STATEMENT

This paper was accepted for publication in the journal Proceedings of the Institution of Civil Engineers Management, Procurement and Law and the definitive published version is available at https://doi.org/10.1680/jmapl.17.00051

\section{LICENCE}

CC BY-NC-ND 4.0

\section{REPOSITORY RECORD}

Cartigny, Tom, and Wayne Lord. 2018. "Evaluating Social Value in the UK Construction Industry". figshare. https://hdl.handle.net/2134/34907. 


\section{Evaluating Social Value in the UK construction industry}

Author 1

- Tom Cartigny, MEng, Design Engineer, Tony Gee and Partners LLP, Stonehouse, Gloucestershire.

Author 2

- Wayne Lord BSc Hons PGDip. Law CEng MICE MIStructE FRICS FHEA Barrister, Senior Lecturer of Construction Law, School of Architecture, Building and Civil Engineering, Loughborough University, Loughborough, Leicestershire UK 


\section{Abstract (150 words)}

A comparative study of contracts tendered in England, Wales and Scotland was conducted to determine the impact of the Public Services (Social Value) Act 2012 ( the Act') on public sector construction contracts. This paper builds on the literature review paper already published by the authors, which set out to define what social value means in the context of public sector works in the UK and under the Act, by assessing the impact on public sector procurement in the UK. A broad method of measurement for social value in public sector construction contracts is developed before reviewing published contracts (tendered and awarded) on the Official Journal of the European Union website. The study has found that the Act has had little impact on England, where social value was already being considered; however, there has been a significant increase in attempts to incorporate social value associated with construction projects in both Wales and Scotland.

\section{Keywords chosen from ICE Publishing list}

Social Sustainability; Social Construction; Social Impact; Social Value; Community

Benefits; Social Measurement; Public Services (Social Value) Act 2012;

\section{List of notation (examples below)}

The Act Public Services (Social Value) Act 2012

SVA The Social Value Act

EU European Union

OJEU Official Journal of the European Union

VCSE Voluntary Companies \& Social Enterprise

PIN Prior information Notice - Brief Description of project and key dates

CIN Contract Information Notice - Detailed description of project and the procedure for procurement

AIN Additional Information Notice - These were short and clarified certain conditions in the CIN.

CAN Contract Award Notice - These held all the information on the parties awarded the contract. 


\subsection{Introduction}

'Social value' is the term used to describe the added value of a project or initiative, not in the monetary sense, but as a benefit to a community's efficacy and or an individual's network of connection and trust in their community. It is often required by politicians as a consideration for large public projects.

The Public Services (Social Value) Act 2012 ('the Act') is a piece of UK legislation which aims to increase the social value provided to the relevant geographical area when public contracts are awarded. The lack of understanding and the generalisation of social value in the Act have resulted in the Act being easily circumvented and passed off as bureaucracy. Although the Act does not strictly cover works contracts, it has been adopted by large infrastructure providers and appears in various works contracts.

Aspects of the Act conflict with the EU public procurement directive which provides that no contract or tender can benefit a local bidder (EC, 2014). The engagement of a local workforce can provide significant added value to a community; however, local contractors cannot be a contract requirement or award criteria in a tender. This is due to the EU directives and associated competition law, which were brought in to eliminate market powers influencing government policies.

Social value is the term used to describe the added value of a project or initiative, not in the monetary sense, but as a benefit to a community's efficacy and or an individual's network of connection and trust in their community. It is often required by politicians as a consideration for large public projects.

\subsection{Aim}

This paper builds on an earlier paper which set out to define the social value of public sector construction contracts (Cartigny and Lord, 2017) and aims to develop a method of measuring social value in construction contracts across the UK. Publicly available contract data were used 
to determine the extent to which social value was included in UK construction contracts, and hence assess the impact that the Act had on public procurement. As a conclusion to the study, this paper has proposed a framework to incorporate and monitor social value in the construction industry.

\subsection{Literature Review}

The Act reads that it requires economic, social and environmental well-being in connection with public services contracts; and for connected purposes' (Public Services (Social Value) Act 2012). The Act insists that the social value of public contracts be considered; however, it omits a definition for social value and establishes no framework nor mechanism to assess this. See the following extract from the Public Services (Social Value) Act 2012 (section 1, subsection (3)).

(3) The authority must consider-

(a)how what is proposed to be procured might improve the economic, social and environmental well-being of the relevant area, and

(b)how, in conducting the process of procurement, it might act with a view to securing that improvement.

Public Services (Social Value) Act 2012

A report commissioned by the Cabinet Office reviewed the operation of the Act and found three issues: awareness of the act was mixed; differing views of how to apply the act (defining social value, applying social value in procurement and use pre- procurement); and methods of measuring social value were not developed (HMG, 2015).

The report, which consulted 214 local authorities, however, conducted no quantitative assessment of the impact of the Act. 'Social value' is a term used to describe a subject that has continuously reappeared in political history. A report on revaluing construction by the International Council for Research and Innovation in Building, published in 2005, set an agenda 
to consider the impact of construction holistically and move towards an integrated stakeholder vision in order to maximise value (Barret, 2005).

\subsection{Social Value in Construction}

Key sources of literature that assisted in defining social value at the individual level were found in sociology journals; refer to the first part of the study by Cartigny and Lord (2017) for further discussion.

Studies on communities measured a number of attributes: attitude to governance (Knack and Keefer, 1997); newspaper readership (Putnam et al., 2004); and legislation innovation (Stanley and Hensher, 2012).

The study on social value in construction concluded that social value can be provided at two scales: communitywide and through individuals. Communities can benefit through jobs, training opportunities and use of local resources provided by construction projects. Attention to social value can improve networking opportunities and improve the transparency through community consultations (Cartigny and Lord, 2017). In the spirit of the Act, all stakeholders should aim to secure these benefits in the procurement of a projects.

\subsection{Methods of Measurement}

Measuring the benefit of social value comprises valuing the difference between the output and outcome of a social benefit. Most methods for measuring social value focus on the financial efficacy of a programme; these typically involve placing a financial value on a social benefit. In contrast, a basic efficiency resource (BER) analysis is an exercise undertaken to compare the efficiency of different schemes (Cugelman and Otero, 2010). A key output of a BER analysis comprises a table comparing the efficiency of different schemes; such table on social benefits in a local area could be incorporated into tenders to ensure that contractors can target their social value benefits more efficiently.

\subsection{Published Guidance on the Act by Procurers}


A review of guidance documents issued by local authorities to acting commissioners focused on targeting the awards criteria and 'other considerations' sections of tenders to incorporate social benefits (Croydon Council, 2013; Knowsley Council, 2013; Macfarlane and Cook 2002).

\subsection{Summary}

Key terms highlighted in the literature will be used to determine if there is any evidence of social value being targeted in construction projects. The literature review conducted by Cartigny and Lord (2017) concluded with a list of key terms; see the following summary

- Trust

- Community

- Training

- Apprenticeships

- Local Supply Chain

- Social consideration

- Community benefits

- Community participation

\subsection{Methodology}

This study has identified contract information and award notices as the primary source of data. The theory gathered in the previous study, summarised in this study's literature review, has been used to develop a characterisation of social value; see Section 2.1. This definition has been used to determine whether a series of contracts has any social value associated with it or not by conducting a review of available tender and contract documents. Contracts issued before and after the Act were compared to determine whether the Act has had an impact on UK construction practice.

This study's epistemology is in line with a quantitative study, as it comprises deductive research where written data are converted into numerical data and statistically analysed to answer a hypothesis. 
A contract notice issued after implementation of the Act is more likely to have social value associated with it, than those contract notices issued before the Act.

This implies a null hypothesis:

A contract notice issued after the implementation of the Act is unlikely to have a more or less social value associated with it, than a contract notice issued before the Act.

\subsection{Data Sampling and Collection}

In order to make the size of data manageable, a data sampling strategy was developed. Contracts available on the Official Journal of the European Union (OJEU) website were used, specifically the Tenders Electronically Daily section, where searches on archived contracts can be performed. The search parameters comprised UK 'works' contracts (Common Procurement Vocabulary codes: 45000000 and 71000000) between January 2009 and December 2015. Data were collected from both contract information notices (CINs) and contract award notices (CANs). (A CIN is a detailed description of project and the procedure for procurement. A CAN holds all the information on the parties awarded the contract.)

Three randomly selected contracts before the Act and three after from each county council have been chosen from England and Wales and likewise for each of the Scottish regions. The application of the Act in Wales is limited, and it does not apply to Scotland; therefore the Act is applicable to contracts procured by predominantly English authorities (Public Services (Social Value) Act 2012: clause 11). Welsh and Scottish data were collected to act as a comparison, although connections and influences from England procurement best practice cannot be ruled out. The Procurement Reform (Scotland) Act 2014 refers to 'community benefits', a term linked with social value; however, it did not come into force until 2016, outside the data collection window for this study (Scottish Government, 2015). 


\subsection{Data Analysis}

The award criteria identified in the notices by the awarding authority were reviewed for key terms associated with social value. Where available, other tender documents were also reviewed for any provisions that suggest social value is being provided. Pre-qualification tenders were also analysed when available for evidence of social merits being required from tendering contractors (Macfarlane and Cook, 2002).

A project/contract was deemed to have had social value either 'targeted' or 'not targeted'. The Act was brought into force in January 2013 , so the notices 'pre' or 'post' the Act were judged on this date. The strength of the appropriate phrases was considered - that is, some projects contained the appropriate terms yet still were deemed as 'not targeted'.

IBM SPSS Statistics 22 was used to perform statistical testing on the collected data. The statistical significance of social value before and after the Act was tested using a chi-squared test. This is a non-parametric test of association between two data sets (Naoum, 2013). The test identifies the likelihood that the observed relationship could have resulted from sampling error (Babbie et al., 2007). This study has used phi and Cramer's $V$ as a measure of the relationship strength (Babbie et al., 2007).

\subsection{Limitations}

The relationship between an increase in social value and implementation of the Public Services (Social Value) Act 2012 has been assumed. There is no direct proof that an increase in social value or no increase will be due to the Act and not a general increase in corporate responsibility.

The data analysed made no specific reference to social value or the Act, but included ingredients that tended towards factors derived from the literature which pointed to social value consideration by implementation. Without an interview, it is difficult to validate whether or not the evidence of social value is present due to the Act or due to good practice. 


\subsection{Results}

The data relating to any social value were often located in the CIN under the additional information, particular conditions or pre- qualification sections. Information on the award criteria was normally in the CAN. Those projects with CIN, additional information notice (AIN; a short notice that clarifies certain conditions in the CIN) and CAN were the most useful and provided the best data source. If the family of contracts had only a prior information notice (brief description of project and key dates) or an AIN, they were discounted and the next notice was selected because there was insufficient information to for the purpose of the research.

\subsection{Analysis of the results}

A total of 256 samples were reviewed from the OJEU notice database. Some counties/regions did not contain enough projects, particularly those in sparse regions of Scotland or Wales. The following results have been explored in this paper

- frequency tables of common terms used in notices;

- association between social value targeted and whether the project was pre- or postimplementation of the Act.

\subsection{Frequency Tables}

The total amount of contracts with social value associated pre and post-implementation of the Act is shown in Table 1.

Table 1 - Countries social value frequency

\begin{tabular}{|l|l|l|}
\hline \multirow{2}{*}{ COUNTRY } & Not & Targeted \\
\cline { 2 - 3 } & Targeted & \\
\cline { 2 - 3 } & Pre/Post & Pre/Post \\
\hline England & $57 / 48$ & $14 / 16$ \\
\hline Scotland & $10 / 2$ & $5 / 12$ \\
\hline Wales & $36 / 12$ & $14 / 26$ \\
\hline
\end{tabular}


The relevant social value terms found in contract documents have been condensed and summarised for England, Scotland and Wales in Table 2.

Table 2 - Social Value terms on contracts documents

\begin{tabular}{|c|c|c|c|}
\hline Social Value Evidence in Notice & England & Scotland & Wales \\
\hline $\begin{array}{l}\text { - } \quad \text { Adhere to: Social policy, Supply chain initiative, Apprenticeship } \\
\text { and Training Targets. } \\
\text { Achievement of social objectives related to participation in } \\
\text { skills development, employment and training programmes. }\end{array}$ & $\sqrt{ }$ & & \\
\hline - $\quad$ Community Benefits apply. & $\checkmark$ & $\checkmark$ & $\checkmark$ \\
\hline $\begin{array}{ll} & \text { Provide socio-economic benefit and SME engagement. } \\
\text { - } & \text { SME Engagement. } \\
\text { - } & \text { Works Suitable for SME. } \\
\text { - } \quad \text { SME engagement and Social Considerations in award criteria } \\
\end{array}$ & $\sqrt{ }$ & & $\sqrt{ }$ \\
\hline $\begin{array}{l}\text { - } \quad \text { Training Targets apply. } \\
\text { - } \quad \text { Achieve Training Targets } \\
\text { - } \quad \text { Provide Training and Work Placements. } \\
\text { - } \quad \text { Evidenticeships, training Scheme, } \\
\end{array}$ & $\checkmark$ & $\checkmark$ & $\checkmark$ \\
\hline - Social Objectives and Social Considerations in award criteria. & $\sqrt{ }$ & $\sqrt{ }$ & $\checkmark$ \\
\hline - To promote Social Value benefits. & $\checkmark$ & & \\
\hline - $\quad$ Apprenticeship and Training evidence in PQQ. & $\sqrt{ }$ & & \\
\hline - $\quad$ Deliver Community Strategies. & $\sqrt{ }$ & & \\
\hline - $\quad$ Adhere to Social Policy and Training Objectives. & $\sqrt{ }$ & & \\
\hline $\begin{array}{ll} & \text { Provide Social Consideration. } \\
\text { - } & \text { SME engagement and Social Considerations in award criteria. } \\
\text { - } & \text { Social considerations, for example provisions relating to local } \\
\text { training initiatives }\end{array}$ & $\sqrt{ }$ & & $\sqrt{ }$ \\
\hline - $\quad$ Project to Regenerate area and provide social amenities. & $\checkmark$ & & \\
\hline $\begin{array}{l}\text { - Achieve Apprenticeship Targets, socio-economic benefit and } \\
\text { SME engagement. }\end{array}$ & & $\checkmark$ & \\
\hline $\begin{array}{l}\text { - Contribute Social Well-being area, } \\
\text { Social, economic and environmental well-being of the wider } \\
\text { community }\end{array}$ & & & $\sqrt{ }$ \\
\hline - $\quad$ Improve Social Vibrancy - Overall project goal & & & $\checkmark$ \\
\hline - $\quad$ Reduce Social exclusion / Increase social inclusion & & & $\checkmark$ \\
\hline - $\quad$ Social Regeneration of the local area. & & & $\sqrt{ }$ \\
\hline - $\quad$ Local Labour & & & $\sqrt{ }$ \\
\hline - $\quad$ Community Engagement & & & $\checkmark$ \\
\hline $\begin{array}{l}\text { - Innovative Ideas to ensure social value, Social objectives / } \\
\text { considerations, }\end{array}$ & & & $\sqrt{ }$ \\
\hline
\end{tabular}

\subsubsection{Meaning/Interpretation}

First, observing the evidence found in the English contract notices, the most prominent word is 'training', followed by 'social policy/considerations', 'SME engagement' (SME: small to mediumsized enterprise) and 'supply chain initiatives'. Training was a common theme found in the literature review. It enhances several aspects of people's social capital by reducing social 
inclusion, increasing both family and work networks (Helliwell and Putnam, 1995; Putnam et al., 2004; Stanley and Hensher, 2012).

'Social policy and consideration' was a fairly blanket term. however, linked back to some social policies that some councils have set out (Croydon Council, 2013; Knowsley Council, 2013). The impact of these was targeted at the council commissioners who are then responsible for producing these notices. SME engagement and supply chain initiatives relate back to the localisation of the supply chain and the impacts on the local area (Cooke, 2012; Sacks, 2002). The key behind this condition in the notices is to maximise the opportunity for smaller local contractors to be involved while not contradicting the EU non-competition law.

The same observation for the Scottish analysis yields different results. The contract notices from the smaller sample size showed a more uniform set of phrases and terms; the main term being 'community benefits'. This relates back to the literature review where the report on community benefits by Macfarlane and Cook (2002) promotes the use of community benefits in contracts by explaining the relevant laws and how not to contradict EU directives. Alongside this were the same observations discussed earlier relating to training/apprenticeships and SME engagement.

The Welsh evidence for social value was in line with the Scottish terms, with 'community benefits' being the most prominent term (Macfarlane and Cook, 2002). The references to SME engagement were also there; however, the training opportunities are referred to as opportunities and placements. Welsh contract notices contained terms which almost directly quoted the Act: 'social, economic and environmental well-being of the wider community' or 'contribute to social well-being'. The Welsh statements and conditions in the notices were much clearer and direct in comparison to the English and Scottish. Perhaps there is additional motivation for Welsh authorities to gain added value from infrastructure projects due to the decline of the manufacturing sector in Wales having a negative impact on communities.

Many of the English and Scottish notices referred to 'social considerations' and 'social policy', which incline towards more rules and regulations, in contrast to some Welsh phrases which contained more positive terms: improve social vibrancy, innovations and ideas to ensure social 
value. The best way to portray this is using a term that all the countries used and highlighting their differences; see $\underline{\text { Table } 3}$.

Although this is a relatively small difference, 'engagement' suggests the need to contact SME as a project add-on, in contrast to 'maximise SME opportunities', which has a positive sound and requires uptake from both the contractor bidding and the local MEs.

Table 3 - Evidence in difference stances on social value

\begin{tabular}{|l|l|}
\hline Country & Small Medium Enterprise References Phrase in Notices \\
\hline England & \multirow{2}{*}{ SME engagement } \\
\hline Scotland & \\
\hline Wales & Maximise SME opportunities \\
\hline
\end{tabular}

Although this is a relatively small difference 'engagement' suggests the need to contact SME as a project add on. In contrast to 'Maximising...Opportunities' which has a positive sound and requires uptake from both the contractor bidding and the local SME's.

\subsubsection{Comparison and summary}

It was not the intention of this study to use the preceding discussion as a statistically significant result, but simply to illustrate an overall picture of the condition of the construction industry's interaction and contribution to communities and social aspects of everyday life.

\subsection{Statistical Analysis}

To calculate the significance of the relationship the research hypothesis must be tested; see Section 3. The significance of the test was calculated using the SPSS package for a chi-squared test of association. Phi and Cramer's coefficient were also calculated using the package to determine relationship strength. Pearson's coefficient is calculated by SPSS and is a measure of the significance level of the relationship - for example, a coefficient of 0.05 means that the relationship is considered significant for $95 \%$ of the population, while the other $5 \%$ are considered anomalies. A significance level of $5 \%$ has been used for this study, meaning a coefficient greater than $5 \%(0.05)$ results in the null hypothesis being accepted. 
Phi and Cramer's coefficient are suitable for a $2 \times 2$ matrix of association, targeted/not targeted against pre/post. The measure of strength ranges from 0 to 1 , where a value of 0 is considered a weak relationship and a value of 1 is considered very strong.

See $\underline{\text { Table } 4}$ for the results of the analysis using a combination for different counties.

\section{Table 4 - Chi-Squared Test Results}

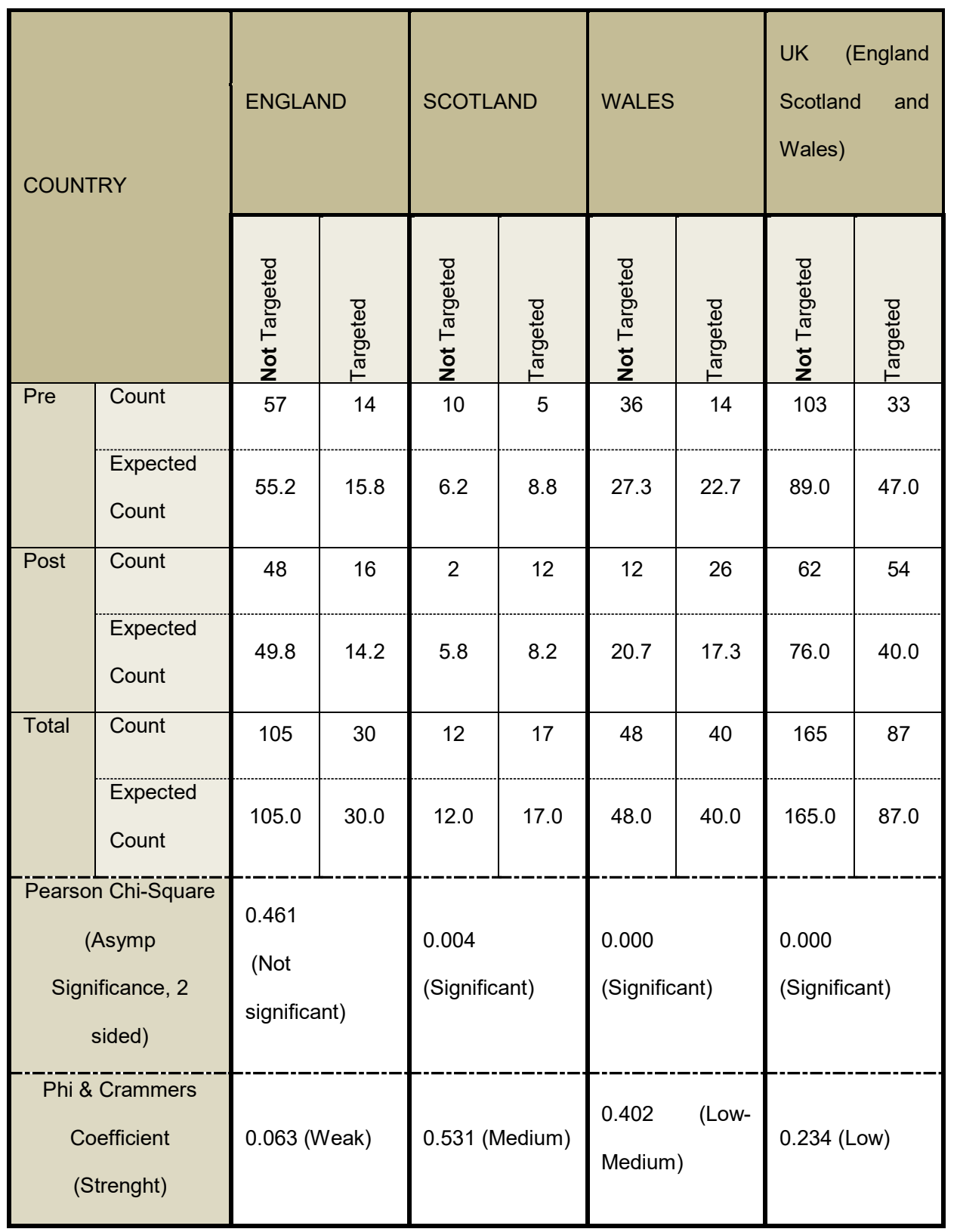




\subsubsection{Interpretation}

Looking at the results for the overall study, for whom the Act applies, for England, the relationship is not significant and weak. This means the following null hypothesis must be accepted for England: 'A contract notice issued after the implementation of the Act is unlikely to have more social value associated with it than a contract notice issued before the Act, in England'.

As noted before, the Act applies to only limited bodies in Wales and does not apply to Scotland. It was intended that Wales and Scotland would enable a comparison to understand whether the trend in social value was due to the implementation of the Act or a general trend nationwide. The results for Wales were very significant and of medium strength, meaning for Wales the null hypothesis is rejected and the research hypothesis accepted: 'A contract notice issued after the implementation of the Act is more likely to have social value associated with it than those contract notices issued before the Act in Wales'.

Combining all the countries together provides a UK-wide picture and results in a significant relationship of medium to low strength, resulting in the research hypothesis being accepted.

If the analysis is conducted by separate countries, it can be seen that England by itself has the least significant and weakest relationship by a large margin; meaning in English county councils, the Act has had no impact, in contrast to Scotland, where the results show that the Act has impact.

Initially, the results are difficult to understand, yet when combining them with some of the discussions which resulted from the frequency tables, it appears that Scotland and Wales had some social value terms and benefits before the implementation of the Act, meaning they have been socially conscious in construction contracts before the Act. On the other hand, for English county councils, there was very little reference before the Act and only a few benefits incorporated into contracts after the Act. 


\subsection{Results Summary}

\subsubsection{Frequency}

The phrases and terms showed links back towards themes found in the literature review. This will aid in constructing a framework series of recommendations. Some of the countrywide themes help to identify the trends on the relationships in the following sections.

\subsubsection{Chi-Squared}

The relationship for England was not significant, resulting in the acceptance of the null hypothesis. However, there was a significant relationship for both Scotland and Wales; it was found that England by itself had the least significant relationship. This was apparent in the phrases and terms in Table 2, where Scotland and Wales have prominent terms before and after, in contrast to England before and after.

\subsubsection{Limitations}

A total of 256 different projects were considered from different county councils in Scotland (29), Wales (91) and England (136). In general, the procedure for determining whether social value was targeted or not targeted was fairly systematic and not objective; most references to social value activities were obvious and direct.

Terminology and activities that were found in the literature review to be associated with social value were found among notices. Key terms relating to social value compiled from the literature review were used as a guide of phrases that were searched for in notices. Where projects referred to a pre-qualification questionnaire $(P Q Q)$, they were not reviewed because $P Q Q$ s were not publicly available. This is a significant limit because PQQs may have mentioned social value in more detail for all countries. There is scope for further investigation in this area.

The outcome variable is ordinal with only a yes or no response. Having a scale variable for this would have allowed for further statistical investigation as to the strengths and commitment that specific projects had in providing social value. However, the notices were only a part of the picture 
and it is difficult to gauge the real value that would be associated with the contract. There is scope for further study on the strength of social value provided, as opposed to what was intended by or written into the contract. This study was limited in scope to ascertaining the condition of public sector procurement in securing social value in construction contracts.

\subsubsection{Notice quality, size, price and type}

In general, notices that were for an open procurement procedure were more complete than those for restricted procurement procedures. Similarly, some county councils produced consistently comprehensive notices and some county councils consistently produced poor notices with little information. Some smaller counties with little construction were dominated by a single project, where all the notices related to the same overall job, yet they were displayed in different notices. Price was normally given as a range in the $\mathrm{CIN}$; in these cases, the greatest monetary value was used.

\subsubsection{Award Criteria}

Few contracts contained specific social value in the award criteria, and if they did, it was weighted low (5-10\%). Many contracts referred to the PQQ documents.

\subsubsection{Evidence}

It is key to note that this research can only deduce whether social value is targeted because from a CAN, it is impossible to tell whether 'social objectives' were met or 'community benefits' were integrated.

\subsection{Conclusion and Recommendations}

This research aimed to understand the impact of the Public Services (Social Value) Act 2012 on a nationwide scale; therefore, a time-efficient method was developed to assess a large number of contract documents before and after the Act across English and Welsh county councils and Scottish regions. 
The OJEU database of contract notices was used as a way of measuring whether social value had been targeted on a project. The literature review showed the award criteria, additional information and particular conditions sections were locations where commissioners could demonstrate the requirement for social value on a project (Macfarlane and Cook, 2002; Social Enterprise UK, 2012, 2013). The notices were randomly sampled from each county council in England, Wales and Scotland before and after the Act in order to determine whether there had been a change in social value targeted in contracts.

A statistical test of association was used to analyse this relationship, as the result variable for each contract was ordinal. An ordinal variable was used because it was difficult to provide a score scale variable from the contract notices, as they contained minimal information on social value.

\subsection{Concluding remarks}

It can be concluded that the Public Services (Social Value) Act 2012 has not impacted contracts in public infrastructure projects in England, with no significant increase in social value conditions and/or award criteria in contract notices. However, combining the countries, there was a significant increase for the UK as a whole, perhaps showing that Welsh and Scottish authorities took the Act into account as best practice. This increase will be a recommended avenue for further research. It should be noted that this study aimed to paint a countrywide picture and the use of contract notices to determine targeted social value and may not have shown the actual social value that was provided during the life of a project.

\subsection{Guidelines and Framework}

The literature review has revealed that there is limited guidance on the Act and how to implement it with an aim to securing the provision for social value. As a result, this research aims to provide a conceptual framework to demonstrate how social value should be incorporated into construction projects and monitored thereafter. 


\subsection{Incorporating social value into construction}

Evidence that the Act is targeted towards commissioners was found in the literature review, which suggests incorporating social value within the procurement process as an additional condition or award criterion; this targets the local council commissioners drafting the contract notices (Croydon Council, 2013; Macfarlane and Cook, 2002; Social Enterprise UK, 2012, 2013).

\subsection{Guidance for Commissioners}

The results of the study showed a lack of evidence for social value in contract notices in England. This can be the first point of contact between a bidder and commissioner, so it is important to set out any particular conditions or award criteria early on. Phrases and award criteria have been compiled using the results from the study to create strong messages and conditions which have clear intentions

\section{Other conditions:}

- Maximise SME opportunities by conducting workshops for SME's in the surrounding area to promote and educate on the procurement process.

- Adhere to Training and Work Placements targets set by the procuring authority.

- Engage the community by conducting planning/consultation and educational workshops.

\section{Award Criteria}

- Investing in people

- Training and Apprenticeships

\subsection{Guidance for Bidders}

It is the intention of the Act to ensure that social value is taken into account when awarding contracts. This means that jobs may be won or lost dependent on a bid's ability to demonstrate the social value associated with the awarded contract.

Regarding award criteria and prequalification evidence, there are government-run schemes which are considered to provide social value.

Schemes which demonstrate social value are 
- competent person schemes

- Science, Technology, Engineering and Mathematics Network ambassadors

- Building Research Establishment Environmental Assessment Method assessments

- Investors in People

A summary of these schemes in a bid can be considered as evidence towards social value. For particular conditions, method statements on how those objectives will be fulfilled are key as well as any previous experience in similar roles.

It is the intention of this study that local councils will provide a BER matrix (the procedure is detailed in Section 6.5) of the social benefits that are required on the contract area in tender documents. This information is key for bidders as well as they would need to interpret or contribute towards a BER matrix.

\subsection{Framework to provide and monitor Social Value}

The BER process produces a matrix of different options ranking them on their perceived input against their perceived output, enabling the efficiency to be evaluated (Cugelman and Otero, 2010). Other methods of measuring social value assign a monetary value to the benefit and divide by the total investment to produce a ratio; this is in essence a measure of efficiency (Eurodiaconia, 2013). The basic efficiency method could target communities to identify what amenities or benefits they require; the suggested processes are in the next sections.

\subsubsection{Identify Stakeholders}

Gather the representatives from parties that will be involved in the project's conception right through use of the project, as well as those who will benefit from the broader impacts that the project may have (Table 5). 
A consultation session would enable key issues to be identified in the area, which would then be analysed in the BER matrix. For example, a particular area may have issues on a pathways to a school, low employment and poor amenities.

Table 5 - Typical stakeholders

\begin{tabular}{|l|l|}
\hline Stakeholders & Example \\
\hline Project Representatives & Local Council, Designers, Contractors \\
\hline Community & Parents, Professionals, Local Businesses \\
\hline
\end{tabular}

A consultation session would enable key issues to be identified in the area which would then be analysed in the BER matrix. For example a particular area may have issues on: Pathway to school, low employment, poor amenities etc.

\subsubsection{Produce the Matrix}

These issues identified earlier would become issues that perceived input and output would be questioned on.

\subsubsection{Perceived input}

Question companies bidding for work their perceived input to provide this benefit on a scale of 110. For example

On a scale of $1-10,1$ being no effort/cost and 10 being maximum effort /cost, identify the perceived input to construct an additional footway for the local school.

\subsubsection{Perceived Benefit}

Question those who will be impacted by the benefit to denote the benefit that this will have on a scale of $1-10$. For example 
On a scale of $1-10,1$ minimal benefit and 10 a large benefit, identify the perceived benefit of having an additional footway for the local school.

The average score for each issue from different stakeholder groups is averaged and plotted on a graph (Figure 1).

This graph could then be condensed into a matrix form (Table 6), which could be supplied on all tender documents to allow contractors bidding for work to include social benefits that could be targeted correctly. Different matrices from different stakeholders groups could be compared and analysed to begin to understand discrepancies.

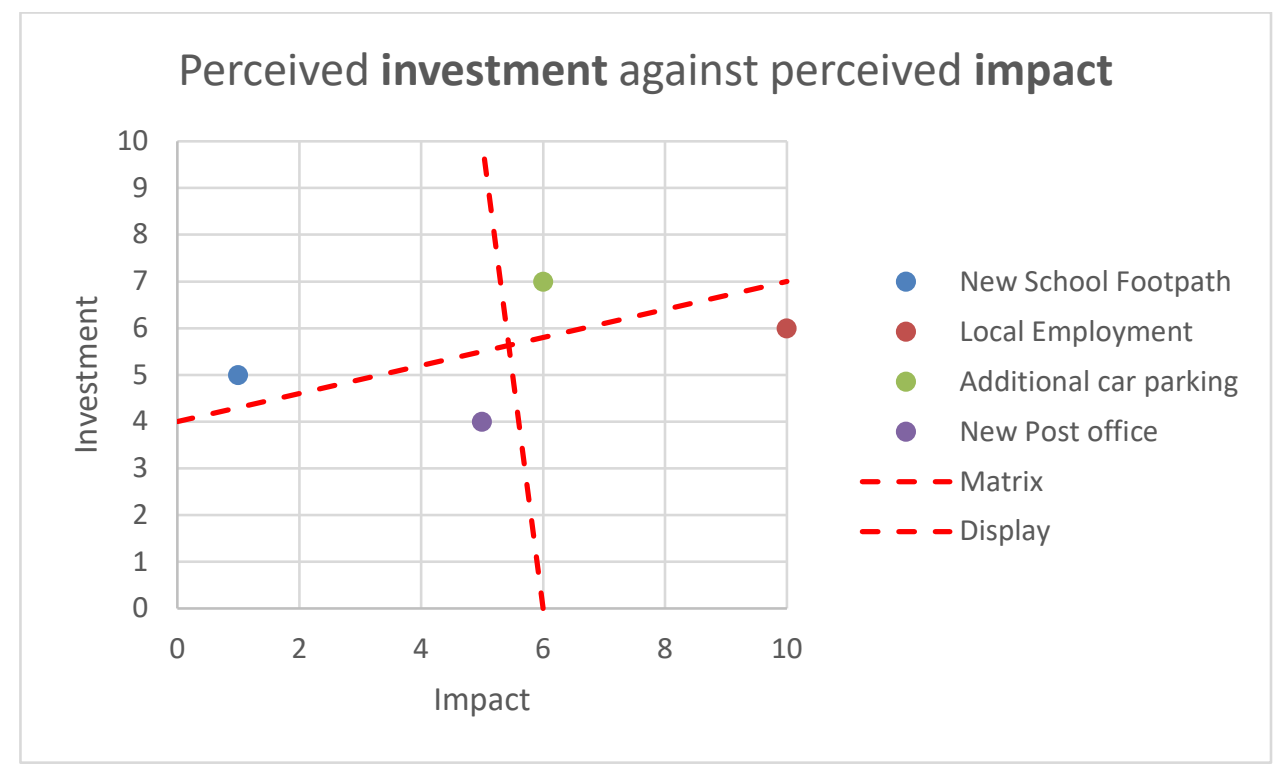

Figure 1 - BER Analysis Examples - Continuous data

This graph could then be condensed into a matrix form which could be supplied on all tender documents to allow contractors bidding for work to include social benefits that could be targeted correctly. Different matrices from different stakeholders groups could be compared and analysed to begin to understand discrepancies.

Table 6 - BER Analysis example - Matrix

\begin{tabular}{|l|l|l|l|}
\hline Investment & High New School footpath & Additional Car Parking \\
\hline
\end{tabular}




\begin{tabular}{|l|l|l|}
\hline \multirow{2}{*}{ Low } & New Post Office & Local Employment \\
\hline Perceived & Low & High \\
\cline { 3 - 3 } Efficiency & Benefit & \\
\hline
\end{tabular}

\subsubsection{Monitor}

Social problems develop as time goes on, so it would be of interest to those using the tool to conduct a communitywide survey on an annual or biannual basis. This survey could include monitoring people's opinions on the impact of the programme against the effort that actually went into it.

Construction-relevant variables which were found in the literature review have been summarised in the list below. These could be integrated into a council's social policy and objectives

- Proportion of working age population in work

- Increase/decrease in all businesses in local area

- Trends in House Prices.

- Numbers in attendance at project consultation events

- Number of Small and Medium local construction suppliers and contractors

- Location of employed subcontractors and suppliers

\subsection{Limitations}

The research measured whether social value had been targeted in a contract notice issued on the OJEU database. Provisions for social value were often provided in the 'additional conditions' section of the notices. From this measurement, it cannot be determined whether social value was actually or will be provided during the project's life. This research recognises that some companies and projects have added value benefits associated with them that will not have been measured due to the method of measurement. 


\subsection{Recommendations}

It has been demonstrated that social value has a plethora of literature and monitoring tools attempting to define the immeasurable entity that is a community's spirit of association or the broader impacts that a social programme has.

Instead of developing techniques to measure social value, perhaps it is more important to produce a tool that enables social value to be targeted more effectively, meaning the monitoring process will grow organically, because the problem and benefit are better understood.

\subsection{Further Research}

The data collected only identified whether or not a contract had the 'intention' of providing social value. This leaves potential for a qualitative line of research to determine whether those projects that had intended on providing social value did or failed in doing so.

\subsection{Acknowledgements}

The author would like to thank all parties who provided valuable information and guidance throughout the study.

\subsection{References}

Arvidson, M. \& Kara, H. (2013) Putting evaluations to use : from measuring to endorsing social value. Third Sector Research, Working Paper 110

Babbie, E., Halley, F. \& Zaino, J., (2007). Adventures in Social Research: Data Analysis Using SPSS 14.0 and 15.0 for windows 6th ed., Pine Forge Press, Sage Company.

Barrett, P. (2005) Revaluing Construction: A Global CIB Agenda. International Council for Research and Innovation in Building. Rotterdam, The Netherlands.

Bergston, J., Dillman, B. \& Stoll, J. (1985) Public environment amenity benefits of private land: the case of prime agricultural land. Southern Journal of Agricultural Economics, 17(1), 1985, pp.139-149. 
Bourdieu, P. (1986) The Forms of Capital. In J. G Richardson (Ed.), Handbook of theory and research for the sociology of education, p 214-258. New York Greenwood.

Cartigny, T., Lord, W. (2017) Defining social value in the UK construction industry, Proceedings of the Institution of Civil Engineers - Management, Procurement and Law, Volume 170 Issue 3, June 2017, pp. 107-114

CBAbuilder.co.uk, (2014). Cost Benefit Analysis Builder Website: Shadow Pricing, See www.cbabuilder.co.uk/Quant2.html (accessed 15/11/2014)

Creswell, J.W., (2009). Research Design: Qualitative, Quantitative, and Mixed Methods Approaches 3rd ed., Sage Publications.

Croydon Council, (2013) Inspiring and Creating Social Value in Croydon. (Available at https://www.croydon.gov.uk/sites/default/files/articles/downloads/socialvalue.pdf)

Cugelman, B., and E. Otero (2010) Evaluation of Oxfam GB's climate change campaign. Oxfam Rep., 60 pp. [Available online at http://policy-practice.oxfam.org.uk/publications/evaluation-ofoxfam-gbs-climate-change-campaign-119438.]

EC (European Community) (2014) Directive 2004/18/EC of the European Union and of the Council of 28 March 2014 on public procurement and repealing Directive. Official Journal of the European Communities L94/65.

Eurodiaconia, (2013) BRIEFING FOR MEMBERS What do we mean by measuring social value? (Available at http://www.eurodiaconia.org/files/Eurodiaconia policy papers and briefings/Briefing Measuring Social Value.pdf)

Gillespie, J., Knowles, L. (2014) Real Local Change ACEVO and LGA. Available at: https://www.acevo.org.uk/sites/default/files/documents/ACEVO\%20and\%20LGA\%20\%20Real\%20Local\%20Change.pdf [Accessed 25/02/15]

Helliwell, J. \& Putnam, R. (1995) Economic growth and social capital in Italy. Eastern Economic Journal, 21(3), p.295.

HM Government (2014) Review of the Balance of Competences between the United Kingdom and the European Union - Single Market: Free Movement of Persons. London. 
HM Government (2015) Social Value Act Review. London

HM Government (2012) Public Services (Social Value) Act 2012. London: The National Archives.

Jun, E., Kim, W.J., Jeong, Y.H., Chang, S.H. (2010) Measuring the social value of nuclear energy using contingent valuation methodology. Energy Policy 38 (3), pp. 1470-1476.

Knack, S. \& Keefer, P. (1997) Does social capital have an economic payoff? A cross-country investigation. The Quarterly journal of economics, 112(4), pp.1251-1288.

Knowsley Council, (2013). Social Value Statement (Available at http://www.knowsley.gov.uk/PDF/social-value-statement.pdf)

Lee, S. \& Aos, S., 2011. Using Cost-Benefit Analysis to Understand the Value of Social Interventions. Research on Social Work Practice, 21(6), pp.682-688.

Macfarlane, R., \& Cook, M. (2002). Achieving Community Benefits through Contracts: Law, Policy and Practice. (Technical Report to the Joseph Rowntree Foundation). York, UK: The Policy Press.

Manetti, G. (2012) The Role of Blended Value Accounting in the Evaluation of Socio-Economic Impact of Social Enterprises. VOLUNTAS: International Journal of Voluntary and Nonprofit Organizations, 25(2), pp.443-464.

Millar, R. \& Hall, K. (2013). Social Return on Investment (SROI) and Performance Measurement. Public Management Review, 15(6), pp.923-941.

Nahapiet, J. \& Ghoshal, S. (1998) Social Capital , Intellectual Capital , and the Organizational Advantage Janine Nahapiet; Sumantra Ghoshal. Academy of Management Review, 23(2), pp.242-266.

Naoum, S.G., (2013). Dissertation Research \& Writing For Construction Students Third., Routledge, Abingdon, Oxon.

Nicholls, J., Lawlor, E., Neitzert, E. and Goodspeed, T. (2009) A guide to social return on investment. London: Office of the Third Sector, The Cabinet Office.

Olsen, JA., Smith, RD., (2001) Theory versus practice: a review of "willingness-to-pay" in health and health care. Health Econ. 10:39-5 
Putnam, R., I. Light, X. d. S. Briggs, W. M. Rohe, A. C. Vidal, J. Hutchinson, J. Gress, and M. Woolcock, (2004) 'Using Social Capital to Help Integrate Planning Theory, Research, and Practice: Preface.' Journal of the American Planning Association 70:142- 92.

Scottish Government (2015). Scottish Procurement Policy Note: Changes to the public procurement rules in Scotland. Edinburgh, The Scottish Government. SPPN 6/2015.

Social enterprise UK (2014) Communities Count: The four steps to unlocking social value. (Available at http://www.socialenterprise.org.uk/uploads/files/2014/06/communities count final report.pdf)

Sacks, J. (2002) The money trail - Measuring your Impact on the Local Economy using LM3. New Economics Foundation and The Countryside Agency, (2), p.152.

Siisiäinen, M. (2000) Two Concepts of Social Capital: Bourdieu versus Putnam. paper presented at the ISTR Fourth International Conference 'The Third Sector: For What and For Whom?' Trinity College Dublin July 5-8.

Social enterprise UK, (2013). State of Social Enterprise Survey 2013. (Available at http://www.socialenterprise.org.uk/uploads/files/2013/07/the peoples business.pdf)

Social enterprise UK, (2012) The Social Value Guide. (Available at http://www.socialenterprise.org.uk/uploads/files/2012/03/public services act 2012 a brief gui de web version final.pdf)

Socialauditnetwork.org.uk, 2014. Social accounting and audit for the community sector. See www.socialauditnetwork.org.uk/getting-started/what-is-social-accounting-and-audit/ (Accessed on $17 / 12 / 2014$ )

Stanley, J. \& Hensher, D., 2012. Mobility, social capital and sense of community: what value? Urban studies, 49(16), pp.3595-3609.

Wood C and Leigthton D (2010) Measuring Social Value: The Gap between Policy and Practice. London: DEMOS.

\section{Figure captions}

Figure 1 - BER Analysis Examples - Continuous data 
